\title{
Static and fatigue behavior of plug-welded dissimilar metal welds between carbon steel and austenitic stainless steel with different thicknesses
}

\author{
Triyono $^{1 *}$, Jamasri ${ }^{2}$, Mochammad Noer $\| m^{2}{ }^{2}$ and Raden Soekrisno ${ }^{2}$
}

\begin{abstract}
Background: Plug welding was used on the parts of the structure in which spot welding cannot be implemented, such as the complex structure and the construction with the profile stiffener. The objective of the present work is to define the static and fatigue behaviors of the plug-welded dissimilar metal welds between carbon steel and austenitic stainless steel with different thicknesses because the detailed recommendations on it were limited.

Methods: Carbon steel SS400 with a thickness of $3.0 \mathrm{~mm}$ and 1.0-mm-thick austenitic stainless steel SUS304 were plug welded using varied hole diameter in a range of 7 to $13 \mathrm{~mm}$ where the welding current and the diameter of welding wire were kept constant at $80 \mathrm{~A}$ and $1.0 \mathrm{~mm}$, respectively. The welding joints were exposed to tensile shear tests, and the transition of interfacial fractures to tearing fractures was defined as the optimum condition. Tensile peel, fatigue, and corrosion fatigue tests were carried out on the optimum specimens.

Results: The optimum plug welding joints were obtained at the hole diameter of $8 \mathrm{~mm}$ where the tensile peel and tensile shear load bearing capacity were 8.6 and $17.2 \mathrm{kN}$ respectively. The endurance limit of fatigue conducted in air was $2 \mathrm{kN}$, whereas corrosion fatigue samples at this load fail at about 1,000,000 cycles.

Conclusion: AWS's formula for plug weld can be applied to the plug-welded dissimilar metal welds between carbon steel and austenitic stainless steel with different thicknesses. Endurance limit of this joint in corrosive environments is about half of the endurance limit in normal environments.
\end{abstract}

Keywords: Fatigue; Carbon steel; Austenitic stainless steel; Plug welded; Dissimilar metal welds

\section{Background}

Welding of dissimilar metals between carbon steel and stainless steel has been widely used in engineering practice over the years. It is more economical compared to the ones made of stainless steel only. The importance of corrosion resistance in the structures is also the reason for the implementation of dissimilar metal welds. Dissimilar metal weld is generally more challenging and often causes problems due to differences in the physical, mechanical, and metallurgical properties of the base metal to be joined.

The stiffened thin plate structure, where the thinner plate is reinforced by a thicker plate called a frame, has been claimed as being a cost-effective way of achieving a highperformance vehicle structure (Gean et al. 1999). This

\footnotetext{
* Correspondence: triyonomesin@uns.ac.id

${ }^{1}$ Mechanical Engineering Department, Sebelas Maret University, Surakarta 57126, Indonesia

Full list of author information is available at the end of the article
}

structure is generally welded by resistance spot welding due to its advantages in welding efficiency and suitability for automation (Hou et al. 2007). The parts of the structure in which spot welding cannot be implemented, such as the double sheeting structure, complex structure, and the construction with the profile stiffener, plug welding was applied instead of spot welding. Welding schedule of plug welding has been offered by American Welding Society (AWS) (2004) and previous study (Tsuruta et al. 1952). According to this recommendation, the weld quality is achieved when the hole diameter of plug welding is $8+t$ (in $\mathrm{mm}$ ), where $t$ is the thickness of the joined plate (in $\mathrm{mm}$ ). It is very useful in finding good weld schedules for equal-thickness welding, but confusing in that for unequal-thickness plate welding and generally developed by and practiced within individual manufacturers (Agashe and Zhang 2003). Some of them use the thickness of thinner material, and others use the average of joined material thickness in that empirical formula. There 
are a lot of scientific papers dealing with static and fatigue behaviors of spot-welded dissimilar metal joints (Alenius et al. 2006; Hasanbasoglu and Kacar 2007; Jamasri et al. 2011; Vural et al. 2006), but only a few studies have been published concerning those of plug welded. The objective of the present work is to investigate the static, fatigue, and corrosion fatigue of plug-welded dissimilar metals between 3.0- $\mathrm{mm}$ carbon steel and 1.0- $\mathrm{mm}$ austenitic stainless steel.

\section{Methods}

\section{Materials and welding processes}

Carbon steel SS400 with the thickness of $3.0 \mathrm{~mm}$ and 1.0-mm-thick austenitic stainless steel SUS304 were used in this study. The chemical composition and mechanical properties of the test materials are given in Table 1. Gas metal arc weld (GMAW) with argon gas and ER309L filler metal was performed on plug welding process using constant weld current, wire diameter, and weld voltage of 80 A, $1.0 \mathrm{~mm}$, and $38 \mathrm{~V}$ respectively, while the hole sheeting diameter $(d)$ was varied from 7 to $13 \mathrm{~mm}$ by $1-\mathrm{mm}$ increments as illustrated in Figure 1.

\section{Metallographic evaluation and mechanical test}

The transverse section of weld passing through the weld nugget was prepared by standard metallographic procedure. Due to the nature of dissimilar metal welds, a twostage etchant was used for etching. In the first stage of etching, 2.5\% alcoholic nitric acid solution was used to reveal the microstructure of carbon steel side. The microstructure of austenitic stainless steel side and weld metal were revealed using $10 \mathrm{ml}$ nitric acid, $20 \mathrm{ml}$ hydrochloric acid, and $30 \mathrm{ml}$ water. Microstructure investigations were carried out using an optical microscope.

Static tensile shear and peel tests were conducted and the failure mode, weld size, and load to failure were recorded. The samples were made according to the French standards A 87-001 and NF A 89-206 as shown in Figure 2.

The corrosion fatigue testing was performed in laboratory conditions using a 40-kN servohydraulic Shimadzu

Table 1 The chemical composition (wt.\%) and mechanical properties of test materials

\begin{tabular}{lll}
\hline & SS400 & SUS304 \\
\hline Element & & \\
$\mathrm{C}$ & 0.054 & 0.076 \\
$\mathrm{Ni}$ & 0.073 & 8.183 \\
$\mathrm{Cr}$ & 0.044 & 18.107 \\
$\mathrm{Mn}$ & 0.225 & 0.252 \\
$\mathrm{P}$ & 0.094 & 0.031 \\
$\mathrm{Si}$ & 0.154 & 0.389 \\
Yield strength (MPa) & 245 & 305 \\
Tensile strength (MPa) & 388 & 670 \\
\hline
\end{tabular}

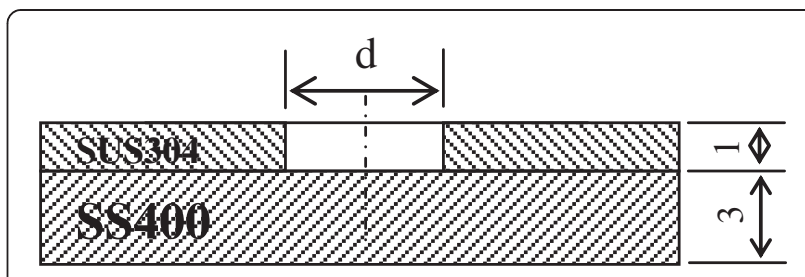

Figure 1 Schematic of plug-welded dissimilar metal joint geometry.

testing machine (Kyoto, Japan) with a software package specifically designed for running fatigue tests. All tests were carried out at room temperature with stress ratio and frequency of 0.1 and $8 \mathrm{~Hz}$, respectively. The test sample was made according to the French standard A 03-405 as shown in Figure 3. It was similar to the samples used from a work which was carried out by Gean et al. (1999).

The corrosion chamber as shown in Figure 4 was used in the corrosion fatigue tests. The chamber was located around the test specimen so that the part of the corrosion fatigue specimen was exposed in stagnant natural seawater of $\mathrm{pH}$ about 8.0 with a salinity of $34.5 \mathrm{~g} \mathrm{NaCl} / \mathrm{l}$. Fatigue tests in air were also conducted as a comparison.

\section{Electrochemical tests}

The corrosion rates of the raw material and plug-welded surface were evaluated using Potensiostat/Galvanostat Model 273 (Princeton Applied Research, Oak Ridge, TN, USA). The samples were mounted in epoxy to expose only one surface with an area of $133 \mathrm{~mm}^{2}$ for electrochemical tests. A saturated calomel electrode (SCE) was used as the reference electrode and a platinum wire was

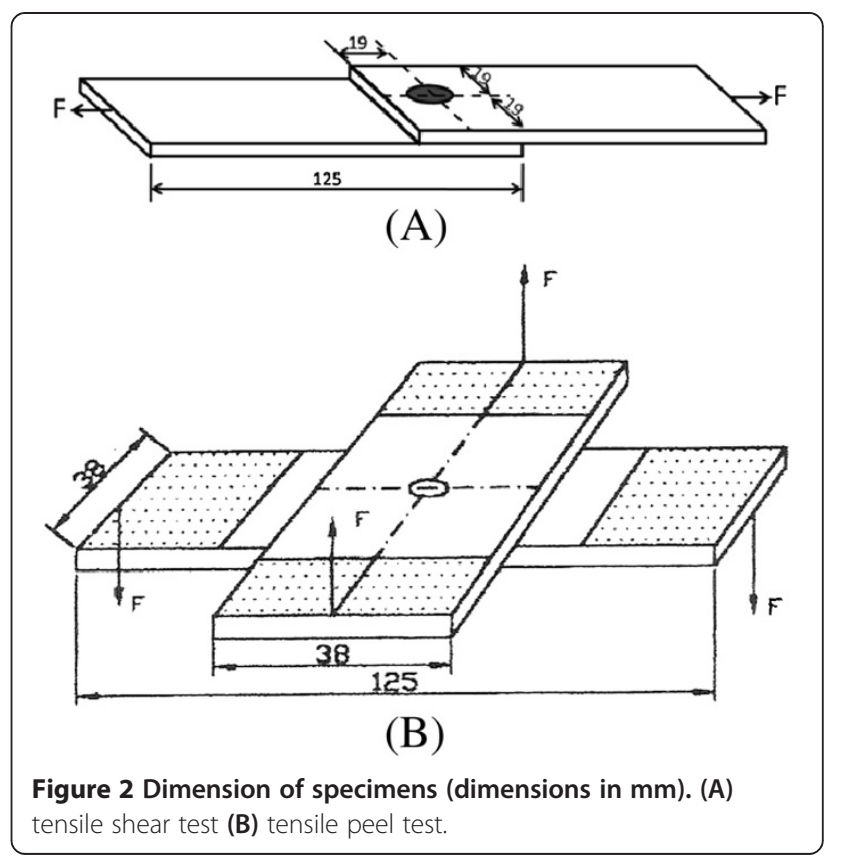




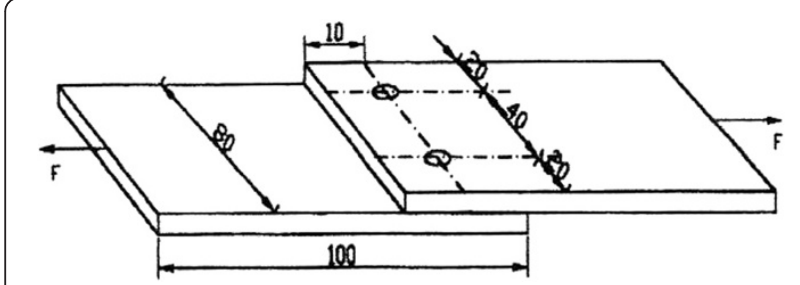

Figure 3 Fatigue specimen (dimension in $\mathrm{mm}$ ).

used as the counter electrode. All electrochemical tests were carried out at room temperature. The polarization was conducted in natural seawater at a potential scanning range from -800 to $+300 \mathrm{mV}$ with a speed of $20 \mathrm{mV} / \mathrm{min}$. Tafel lines were drawn on corresponding graphical plot of $E$ versus $\log I$ to obtain the corrosion current $\left(I_{\text {corr }}\right)$ value.

\section{Results and discussion}

The most important factors that affect plug weld quality are strength, depth, and area of weld penetration (American Welding Society 2002). In order to determine weld quality of plug-welded dissimilar materials, the strength of weldment was also determined. Structures employing plug weld are usually designed so that the welds are loaded in shear when the parts are exposed to tension or compression loading. In some cases, the welds may be loaded in tension, where the direction of loading is normal to the plane of the joint, or a combination of tension and shear (Hasanbasoglu and Kacar 2007).

In this study, the effects of hole diameter on the tensile shear load bearing capacity of the plug-welded dissimilar metals joint are shown graphically in Figure 5. It is found that tensile shear load bearing capacity of welded materials increased with increasing hole diameter.

The enhancement in tensile shearing load bearing capacity of weldment with increasing hole diameter was primarily attributed to the enlargement of penetration size including the depth and diameter of penetration.

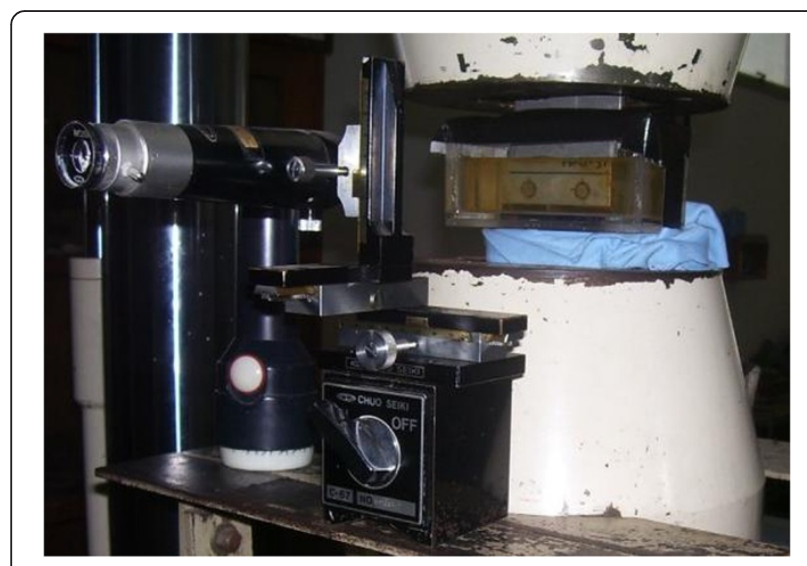

Figure 4 The corrosion chamber used in the corrosion fatigue test.

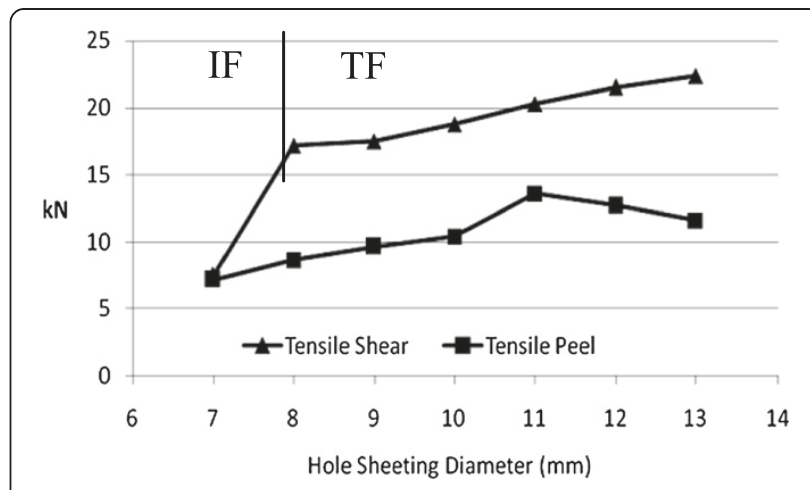

Figure 5 Tensile shear and tensile peel load bearing capacity of welded materials.

Plug-welded material with a hole diameter of $7 \mathrm{~mm}$ had low tensile shear strength bearing capacity due to low penetration size. It had a penetration diameter of $4.8 \mathrm{~mm}$ and a penetration depth of $0.7 \mathrm{~mm}$ (Figure 6A) which led it failed in interfacial fracture mode (IF) as shown in Figure 7A. Tensile shear load bearing capacity would increase if the hole diameter was increased to $8 \mathrm{~mm}$ due to increasing penetration diameter to $6.8 \mathrm{~mm}$ and penetration depth to $1.3 \mathrm{~mm}$ as seen in Figure 6B. It caused the tearing failure mode (TF) as illustrated in Figure 7B. Therefore, because the tearing failure mode

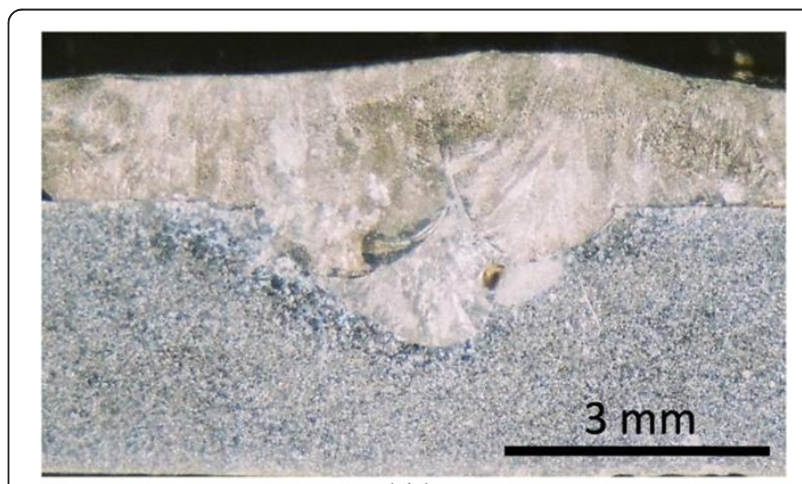

(A)

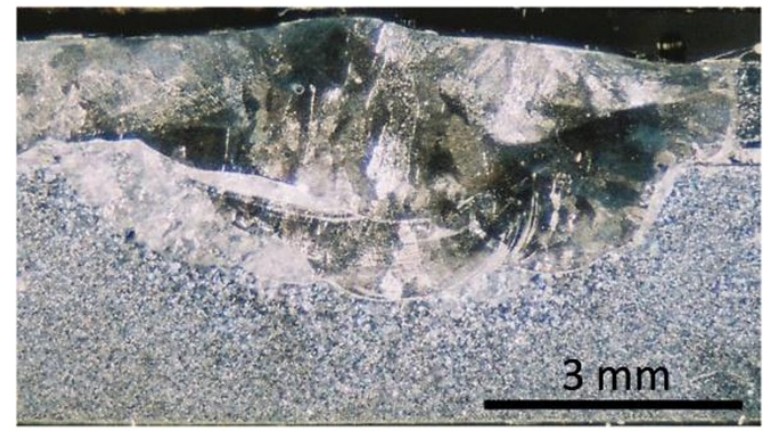

(B)

Figure 6 The macrostructure of plug weld with hole diameter. (A) $7 \mathrm{~mm}$ and (B) $8 \mathrm{~mm}$. 


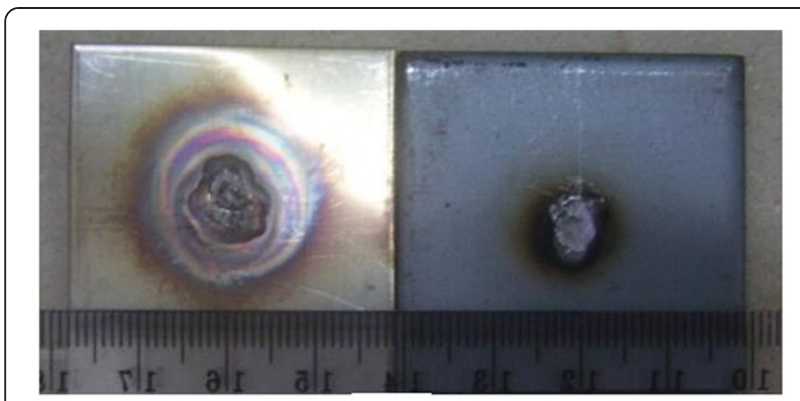

(A)

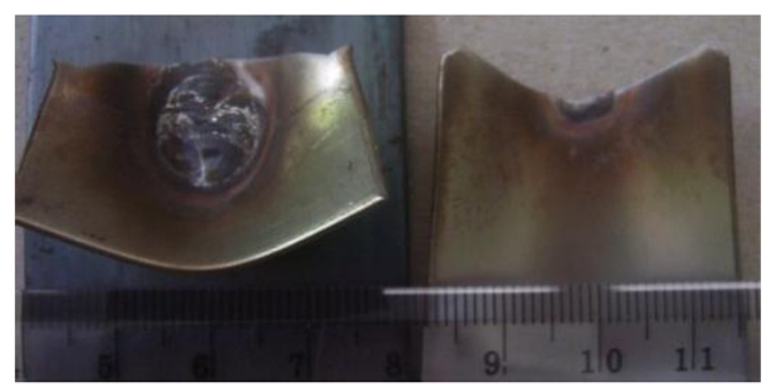

(B)

Figure 7 The fracture mode of tensile shear test samples. (A) $7 \mathrm{~mm}$, and (B) $8 \mathrm{~mm}$.

was guaranteed, hole diameter of $8 \mathrm{~mm}$ was designated as the critical hole diameter which ensured the reliability of plug-welded dissimilar metal between 3-mm-thick carbon steel and stainless steel with a thickness of $1 \mathrm{~mm}$. According to AWS's recommendation, the minimum hole diameter required to ensure reliability of plug-welded materials based on the thinnest joined materials of $1 \mathrm{~mm}$ is $9 \mathrm{~mm}$, while based on the average joined material thickness of $2 \mathrm{~mm}$ is $10 \mathrm{~mm}$. However, as can be seen from Figure 5, even plug-welded material with $8 \mathrm{~mm}$ hole diameter in this study failed in the tearing mode.

Based on the result of the tensile shear test which determined the specimen with a hole diameter of $8 \mathrm{~mm}$ which was the optimum plug-welded joint, fatigue and corrosion fatigue tests were performed on these specimens. The $S-N$ curves, the results of corrosion fatigue and fatigue tests of the plug-welded joints are presented in Figure 8. All data points belong to a mean value of three tests. As shown in Figure 8, while the load range decreases, the fatigue life of the specimen increases as expected. The fatigue specimens in air condition exhibited higher fatigue strength than those in corrosive condition, especially at low stress. There was no inclination going to a specific endurance limit for fatigue in air and corrosion fatigue. The fatigue class (FAT) which was identified by the characteristic fatigue strength of the detail at two million cycles (Hobbacher 2003) for fatigue in air was $2 \mathrm{kN}$, whereas corrosion fatigue samples at this

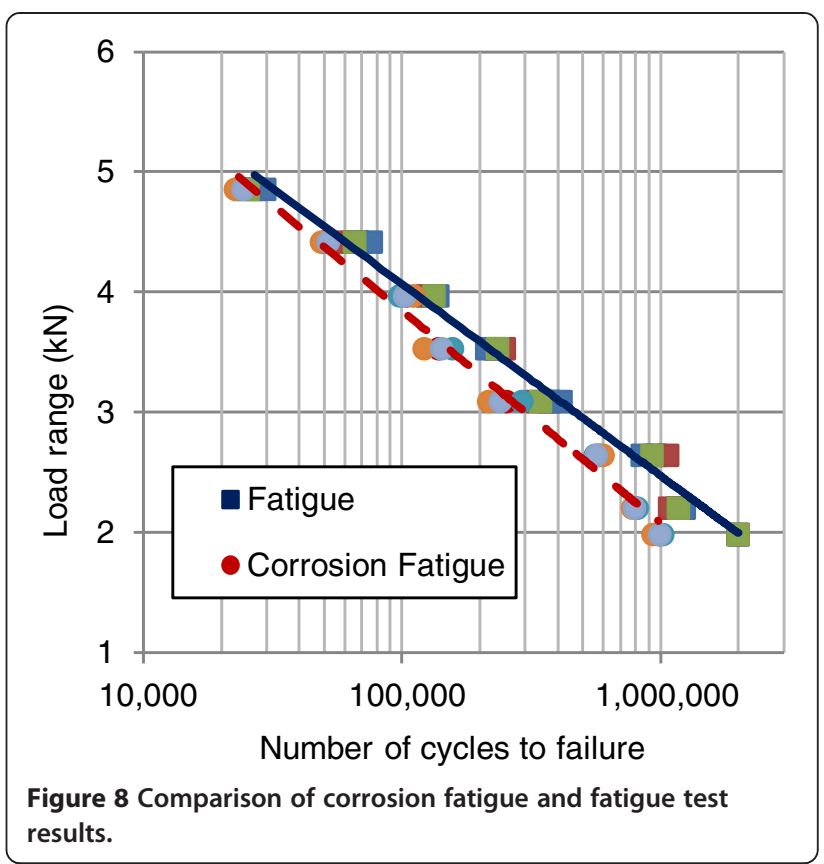

load fail at about $1,000,000$ cycles. It shows that sea water environment decreases remarkably the fatigue strength of the plug-welded dissimilar metals between carbon steel and austenitic stainless steels.

Failures of fatigue in air and corrosion fatigue of plugwelded specimens are in the form of tearing fracture mode as seen in Figure 9. The fatigue cracks started in the weld metal adjacent to the penetration area. After initiation, the crack propagation occurred through the thickness of the thinner sheets and continued propagating through the width of the thin sheet. Finally, this mechanism led to the tearing fracture mode as seen in

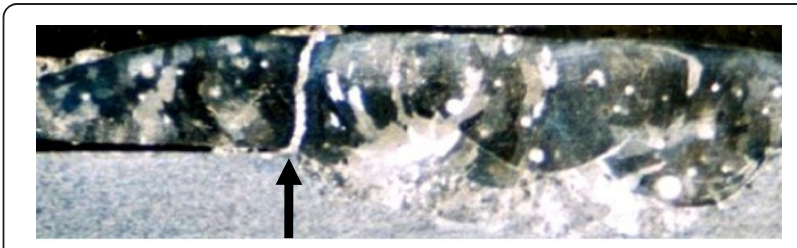

(A)

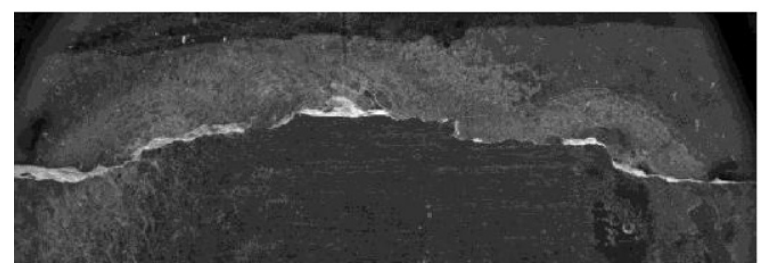

(B)

Figure 9 Failure mode of fatigue (A) Crack location and (B) final failure of corrosion fatigue and fatigue in air. 
Figure 9B. This phenomenon is different from fatigue behavior of spot-welded equal sheet thicknesses which were observed by Vural et al. (2006), Alenius et al. (2006), and Jamasri et al. (2011). They found that the spot-welded dissimilar metal fatigue failures were the interfacial or pullout fracture.

The corrosion fatigue strength weakening was definitely affected by hydrogen embrittlement (HE). It was revealed as microscopic ductile fracture, resulting from hydrogen concentration at crack tips leading to hydrogen-enhanced slip. Figure 10 shows the micrographs of the crack initiation, while Figure 11 shows those of the crack propagation of corrosion fatigue and fatigue in air, which was tested at the same stress level and frequency. They show that the specimens are susceptible to the hydrogen embrittlement in natural sea water. In the fatigue specimen, each striation was regularly formed and roughly triangular in shape. In the corrosion fatigue specimen, on the other hand, striations were irregularly shaped and less obvious compared to those of the fatigue specimen. Many articles have been published to describe this
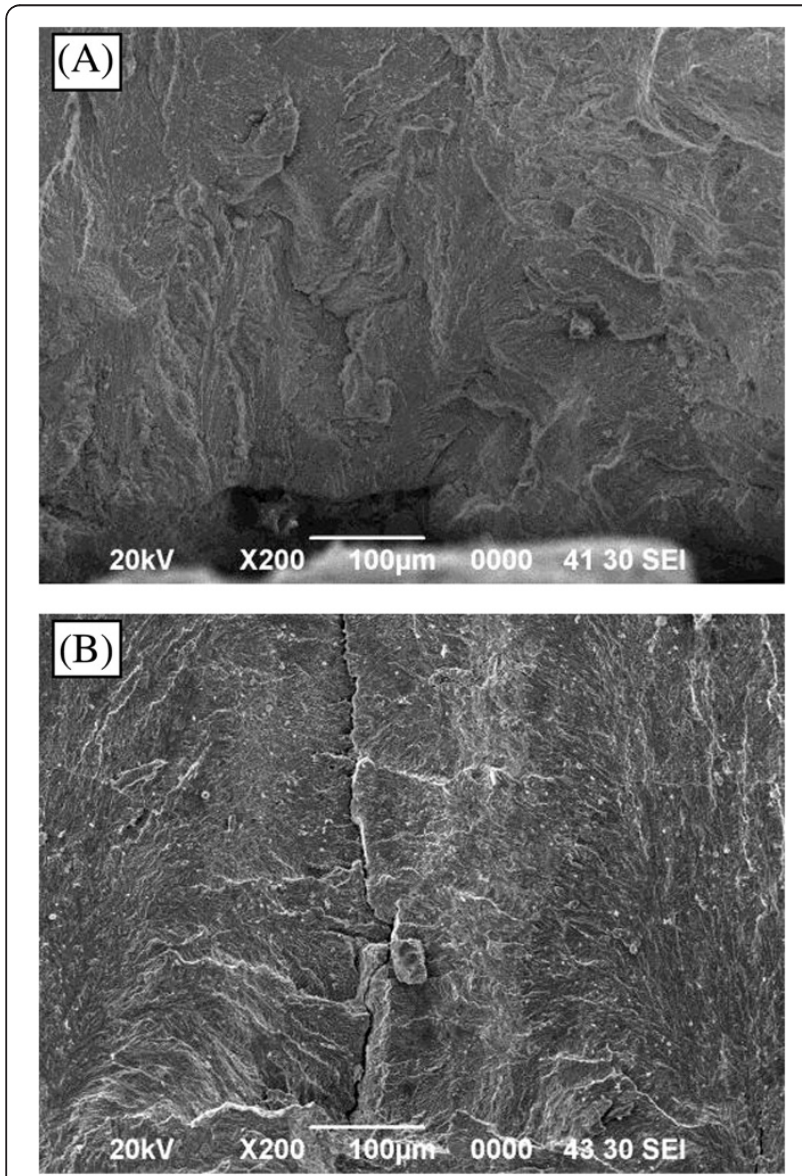

Figure 10 Crack initiation zone. (A) Corrosion fatigue and (B) fatigue in air.
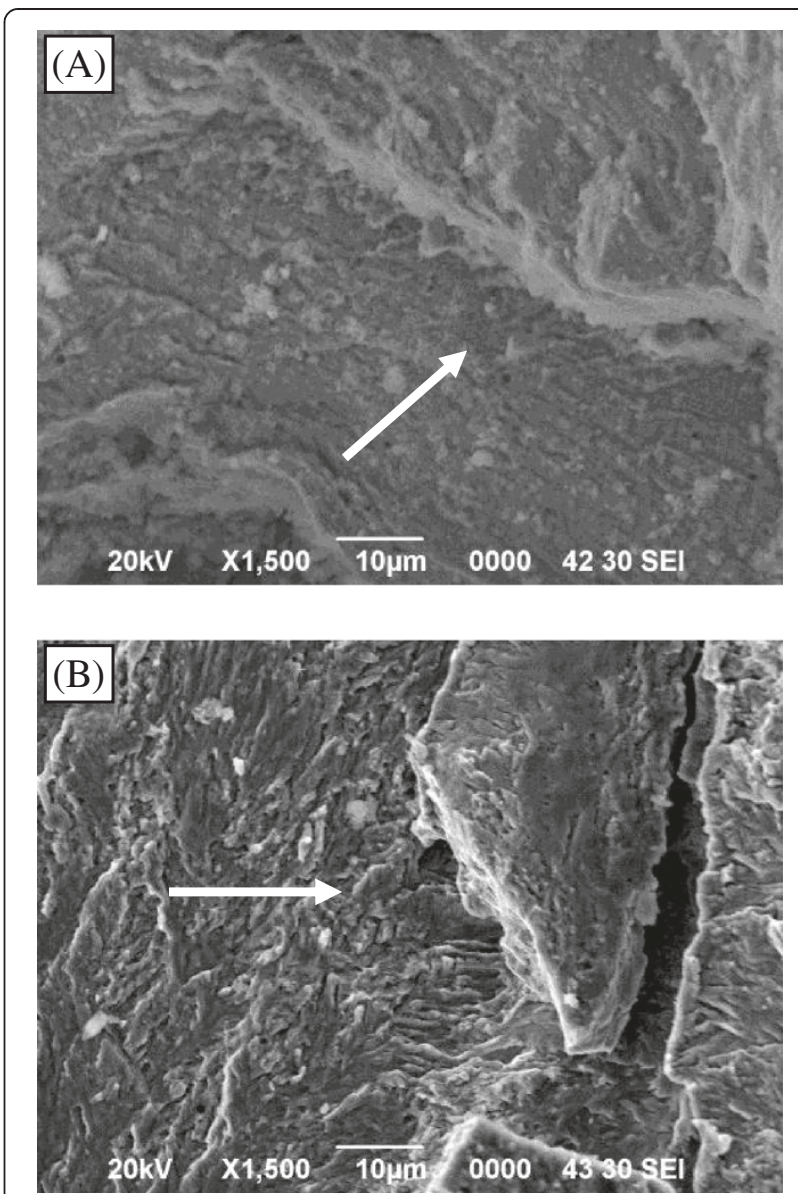

Figure 11 Crack propagation zone. (A) Corrosion fatigue and (B) fatigue in air. The arrows indicate the crack growth direction.

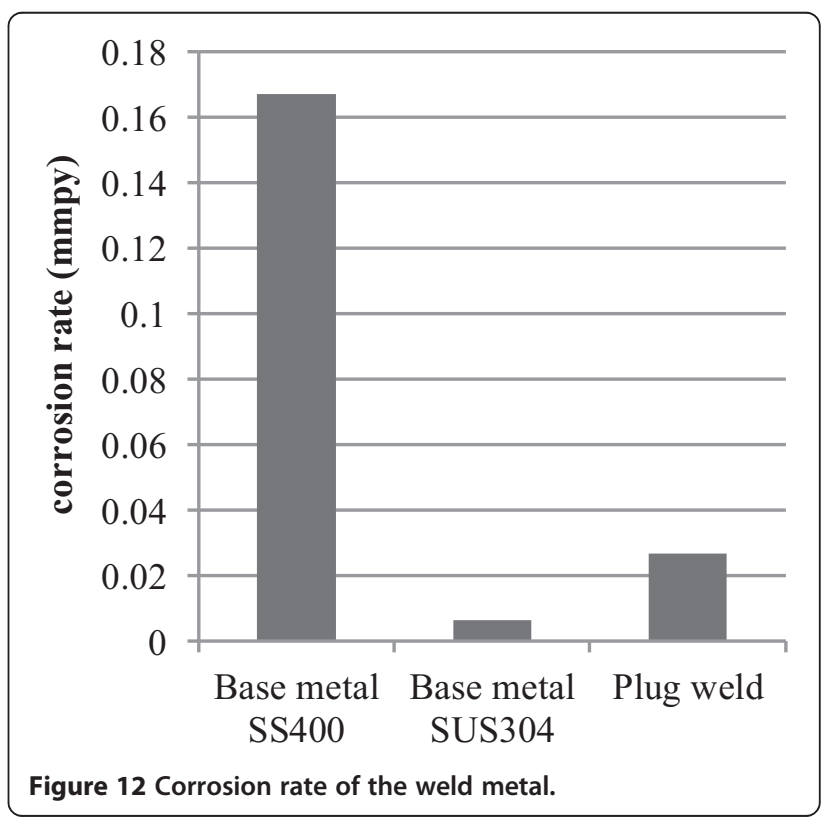




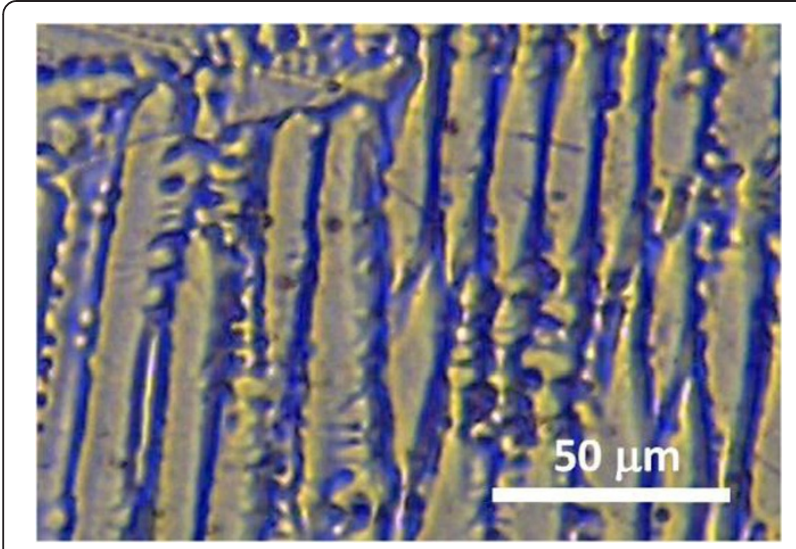

Figure 13 Microstructure of the weld metal.

phenomenon, although they have not agreed on the mechanism of HE (Kim et al. 2003).

HE phenomenon was clarified by the fact that the cracks occurred in the weld metals which have inferior corrosion resistance compared with the base metal (Figure 12). This is due to the fact that the weld metal has an inhomogeneous and dendritic microstructure (Figure 13) with micro-segregation of major elements (i.e., $\mathrm{Cr}$ and $\mathrm{Ni}$ ) as well as minor elements (i.e., $\mathrm{S}$ and $\mathrm{P}$ ) at $\delta-\gamma$ interface boundaries. The non-uniform alloying element concentration around ferrite particles plays a major role in determining the corrosion behavior of such weld metals (Kim et al. 2003). Figure 13 also shows the microstructure of a weld metal consisting of the delta ferrite and austenite phases. Delta ferrite leads to detrimental effects on the corrosion resistance (Pujar et al. 2005).

\section{Conclusions}

Because the tearing failure mode was guaranteed, the optimum plug welding joints were obtained at the hole diameter of $8 \mathrm{~mm}$ where the tensile peel and tensile shear load bearing capacity were 8.6 and $17.2 \mathrm{kN}$, respectively. The endurance limit of fatigue conducted in air was $2 \mathrm{kN}$, whereas corrosion fatigue samples at this load failed at about 1,000,000 cycles.

\section{Competing interests}

The authors declare that they have no competing interests.

\section{Authors' contributions}

J participated in analysis of fatigue data, MNI contributed in micro-structure analysis, RS carried out the corrosion tests. All authors read and approved the final manuscript.

\section{Acknowledgements}

The authors would like to express their sincere gratitude for the financial support of the Ministry of National Education of Indonesia and Indonesian Railway Industry.

\section{Author details}

'Mechanical Engineering Department, Sebelas Maret University, Surakarta 57126, Indonesia. ${ }^{2}$ Mechanical and Industrial Engineering Department, Gadjah Mada University, Yogyakarta 55281, Indonesia.

Received: 6 July 2014 Accepted: 21 August 2014

Published online: 18 September 2014

\section{References}

Agashe, S, \& Zhang, H. (2003). Selection of schedules based on heat balance in resistance spot welding. The Welding Journal, 82(7), 179s-183s.

Alenius, M, Pohjanne, P, Somervuori, M, \& Hanninen, H. (2006). Exploring the mechanical properties of spot welded dissimilar joints for stainless and galvanized steels. Welding Journal, 85(12), 305-s-313-s.

American Welding Society. (2004). AWS D1.1: Structural welding code-steel. Miami: American Welding Society.

American Welding Society. (2002). AWS welding handbook: Welding processes (7th ed., Vol. 3). London: Macmillan Press Ltd.

Gean, A, Westgate, SA, Kucza, JC, \& Ehrstrom, JC. (1999). Static and fatigue behavior of spot welded 5182-0 aluminium alloy sheet. Welding Journal, 78(3), 80-s-86-s.

Hasanbasoglu, A, \& Kacar, R. (2007). Resistance spot weldability of dissimilar materials (AISI 316L-DIN EN 10130-99 steels). Material and Design, $28,1794-1800$.

Hobbacher, A. (2003). Recommendations for fatigue design of welded joints and components, document XIII-1965-03/XV-1127-03. Paris: International Institute of Welding.

Hou, Z, Kim, S, Wang, Y, Li, C, \& Chen, C. (2007). Finite element analysis for the mechanical features of resistance spot welding process. Journal of Materials Processing Technology, 185, 160-165.

Jamasri, IIman, MN, Soekrisno, R, \& Triyono. (2011). Corrosion fatigue behavior of resistance spot welded dissimilar metal welds between carbon steel and austenitic stainless steel with different thickness. Procedia Engineering, 10, 649-654.

Kim, SH, Moon, HK, Kang, T, \& Lee, CS. (2003). Dissolution kinetics of delta ferrite in AISI 304 stainless steel produced by strip casting process. Materials Science and Engineering A, 356, 390-398.

Pujar, MG, Dayal, MK, Mahotra, SN, \& Giv, TPS. (2005). Evolution of microstructure and electrochemical corrosion behavior of austenitic stainless steel weld metals with varying chemical compositions. Journal of Engineering Materials and Performance, 14(3), 327-342.

Tsuruta, A, Arai, Y, \& Tanaka, R. (1952). On the strength of plug welding of thin steel sheets. Journal of the Japan Welding Society, 21(5-7), 144-150.

Vural, M, Akkuş, A, \& Eryürek, B. (2006). Effect of welding nugget diameter on the fatigue strength of the resistance spot welded joints of different steel sheets. Journal of Materials Processing Technology, 176(1-3), 127-132.

\section{doi:10.1186/s40712-014-0017-4}

Cite this article as: Triyono et al: Static and fatigue behavior of plug-welded dissimilar metal welds between carbon steel and austenitic stainless steel with different thicknesses. International Journal of Mechanical and Materials Engineering 2014 9:17.

\section{Submit your manuscript to a SpringerOpen ${ }^{\circ}$ journal and benefit from:}

- Convenient online submission

- Rigorous peer review

- Immediate publication on acceptance

- Open access: articles freely available online

- High visibility within the field

- Retaining the copyright to your article

Submit your next manuscript at $\downarrow$ springeropen.com 